\title{
Ecological impact of fast industrialization inferred from a sediment core in Seocheon, West Coast of Korean Peninsula
}

\author{
Rack Yeon Choi ${ }^{1}$, Heung-Tae Kim², Ji-Woong Yang ${ }^{3}$ and Jae Geun Kim ${ }^{1,4^{*}}$ (D
}

\begin{abstract}
Background: Rapid industrialization has caused various impacts on nature, including heavy metal pollution. However, the impacts of industrialization vary depending on the types of industrializing activity and surrounding environment. South Korea is a proper region because the rapid socio-economical changes have been occurred since the late nineteenth century. Therefore, in this study, we estimate the anthropogenic impacts on an ecosystem from a sediment core of Yonghwasil-mot, an irrigation reservoir on the western coast of Korea, in terms of heavy metal concentrations, nutrient influx, and pollen composition.

Results: The sediment accumulation rate (SAR) determined by ${ }^{210} \mathrm{~Pb}$ geochronology showed two abrupt peaks in the 1930s and 1950s, presumably because of smelting activity and the Korean War, respectively. The following gradual increase in SAR may reflect the urbanization of recent decades. The average concentrations of arsenic (As), copper $(\mathrm{Cu})$, and lead $(\mathrm{Pb})$ during the twentieth century were $>48 \%$ compared to those before the nineteenth century, supporting the influence of smelting activity. However, at the beginning of the twenty-first century, the As, $\mathrm{Cu}$, and $\mathrm{Pb}$ concentrations decreased by $19 \%$ compared to levels in the twentieth century, which is coincident with the closure of the smelter in 1989 and government policy banning leaded gasoline since 1993. The pollen assemblage and nutrient input records exhibit changes in vegetation cover and water level of the reservoir corresponding to anthropogenic deforestation and reforestation, as well as to land-use alteration.
\end{abstract}

Conclusions: Our results show that the rapid socio-economic development since the twentieth century clearly affected the vegetation cover, land use, and metal pollutions.

Keywords: Heavy metal pollution, Industrialization, Smelter, Pollen analysis, Water level, Sediment core

\section{Introduction}

ince the industrial revolution, industrial activities have affected the Earth's climate and environment in regional to global scales in various aspects, including soil pollution, land use, and vegetation (Mackereth 1966; Bradbury and van Metre 1997; Kim and Rejmánková 2001). These pieces of knowledge are of particular importance

\footnotetext{
* Correspondence: jaegkim@snu.ac.kr

'Department of Biology Education, Seoul National University, Seoul 08826, South Korea

${ }^{4}$ Center for Education Research, Seoul National University, Seoul 08826, South Korea

Full list of author information is available at the end of the article
}

for the assessment of impact by the expansion of anthropogenic activity, as well as for mitigation of future environmental disturbances in developing or emerging industrializing countries, whose global share of manufacturing value added per capita (MVA) is increasing (Facevicova et al. 2020).

Korean Peninsula has been one of the most rapidly industrialized regions in the world since the last twentieth century, and it is therefore suitable for studying the environmental influences of rapid industrialization and accompanying socio-economic changes. The industrialization in Korea has been mainly focused on the coastal area (Kim 2005). Previous studies conducted

(c) The Author(s). 2020 Open Access This article is licensed under a Creative Commons Attribution 4.0 International License, which permits use, sharing, adaptation, distribution and reproduction in any medium or format, as long as you give appropriate credit to the original author(s) and the source, provide a link to the Creative Commons licence, and indicate if changes were made. The images or other third party material in this article are included in the article's Creative Commons licence, unless indicated otherwise in a credit line to the material. If material is not included in the article's Creative Commons licence and your intended use is not permitted by statutory regulation or exceeds the permitted use, you will need to obtain permission directly from the copyright holder. To view a copy of this licence, visit http://creativecommons.org/licenses/by/4.0/. 
at the eastern and southern coasts of the Korean Peninsula observed the heavy metal pollution caused by industrial complexes, including refineries and factories, since the 1960s (Kim 2005; Kim and Kim 2010; Cho et al. 2015). However, nevertheless, the industrialization on the western coast started earlier than that on the eastern and southern coast by the construction of railroads and ports to facilitate rice exportation during the early twentieth century, and the environmental impact at the western coast of the Korean Peninsula has not been paid much attention not only because this region is more characterized by agricultural land and estuaries but also because the modern industry has largely been developed on the southeastern coast of the Korean Peninsula. Furthermore, a large smelter was constructed at the southwestern edge of the Seocheon area, in front of the estuary between the Geum River and the Yellow Sea. The smelting activities have induced heavy metal pollution of soil (Kim and Baek 1994; Kim et al. 1996; Woo et al. 2010; Jeong et al. 2011); however, its impacts on nearby lacustrine and wetland environment have not been well studied around this region.

This study aims to reconstruct the hydrological, ecological, and environmental changes during the rapid industrialization of the west coast of Korea in recent decades. To do this, we analyzed sediment accumulation rate (SAR), pollen assemblage, and heavy metal concentrations from a sediment core drilled at Yonghwasil-mot, a lake located in Seocheon, West Coast of Korea. The laminated sediments in various environments record the past ecological and environmental changes in time order. Therefore, together with a proper age-depth model, a sediment core allows us to quantify the impacts of recent industrialization, such as trace-metal and road dust contamination by urbanization during the last three decades (e.g., Yu et al. 2012), or polycyclic aromatic hydrocarbon concentrations associated with the growth of population and development of social infrastructures (e.g., Liu et al. 2012). In addition, to obtain an independent, reliable chronology in multiannual to decadal time scales for the recent decades, our sediment core was dated by the short-lived radioactive lead-210. Therefore, this study will contribute to our better understanding of the extent and mechanism of the environmental and ecological imprints of rapid industrialization through the twentieth century on the West Coast of Korea.

\section{Site description and sampling}

Seocheon is located in the southwestern part of the Korean Peninsula $\left(35^{\circ} 59^{\prime}-36^{\circ} 11^{\prime} \mathrm{N}, 126^{\circ} 52^{\prime}-126^{\circ} 30^{\prime} \mathrm{E}\right)$.

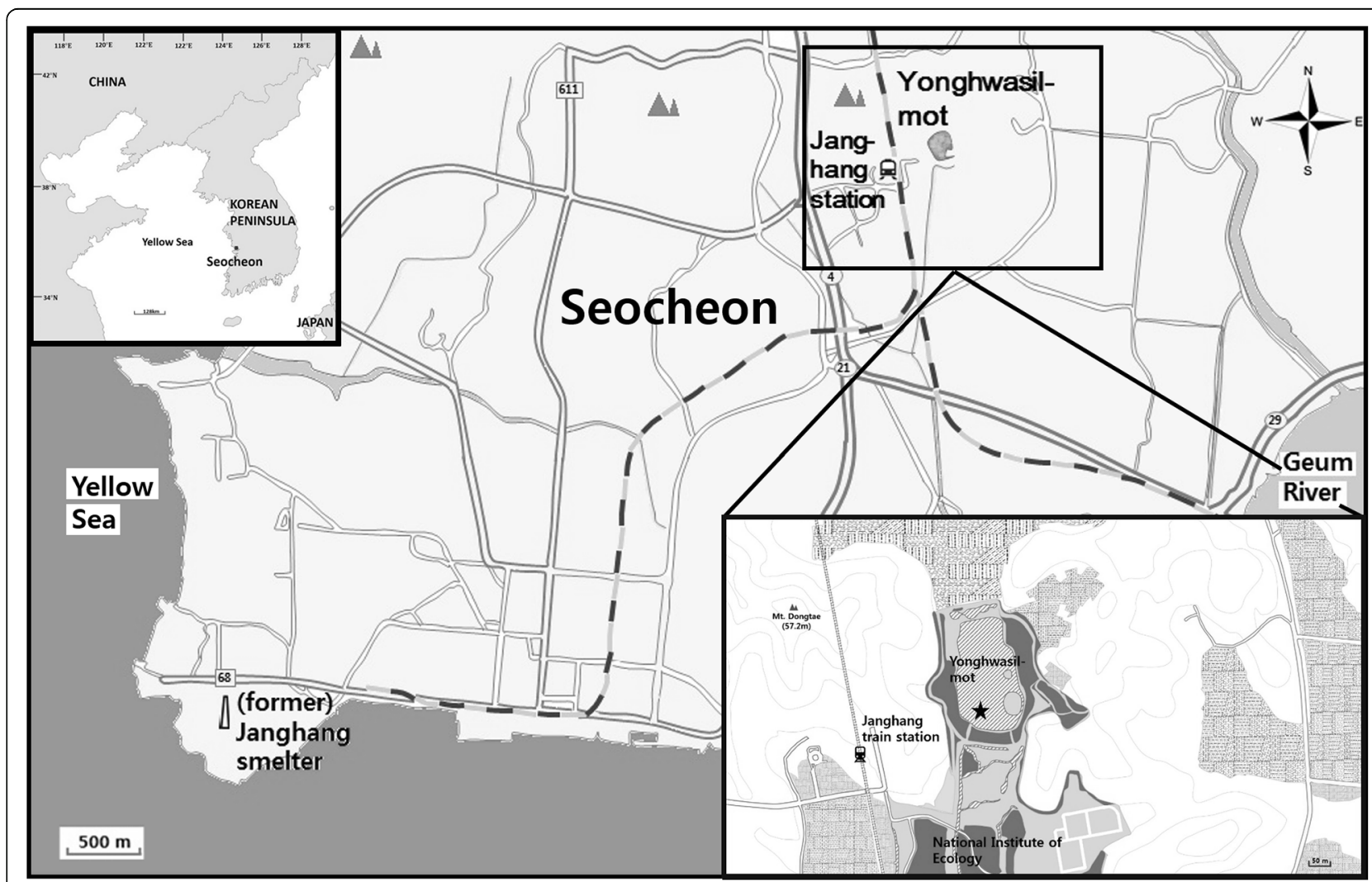

Fig. 1 A map of Seocheon, western coast of the Korean Peninsula showing the locations of the study site (Yonghwasil-mot) and the Janghang smelter. The right inlet is the enlargement around the sampling site (black star) 
It is in the vicinity of the West Sea to the west and is close to the Geum River to the south (Fig. 1). Yonghwasil-mot (Yonghwasil Reservoir or Deogam Reservoir, $36^{\circ}$ $04^{\prime} \mathrm{N}, 126^{\circ} 72^{\prime} \mathrm{E}$ ), which was built for the purpose of irrigating paddies at least 100 years ago (Kim 2012), has an area of $30,000 \mathrm{~m}^{2}$ in an elliptical shape. The study area includes a hilly plain less than $100 \mathrm{~m}$ above sea level with marine alluvial deposits due to land reclamation. Bedrock around the reservoir consists mainly of Precambrian granite gneiss (Song et al. 2008). The Janghang smelter was constructed about $6 \mathrm{~km}$ southwest of the study site in 1936 . About $90 \mathrm{~m}$ of the smoke stake of the Janghang smelter was constructed on the top of the Mt. Jeonmang, whose elevation is $56 \mathrm{~m}$ above sea level. Yonghwasil-mot is presently located at the northern edge of the National Institution of Ecology (NIE). It was dredged during the construction of the NIE.

In March of 2011, we collected a sediment core with a depth of $60 \mathrm{~cm}$ by driving a $5.5-\mathrm{cm}$-diameter plastic open-end sampler into Yonghwasil-mot when the reservoir was drained for dredging. The core was immediately transported to the laboratory in a cooler and kept in a freezer. The frozen core was sectioned into 1-cm-thick samples. About $1 \mathrm{~g}$ of wet sediment was subsampled for pollen analysis. The remaining amount of each sample was dried at $60{ }^{\circ} \mathrm{C}$ and ground with a ball mill (Pulverisette 23 mini-mill, Fritsch, Germany) for physical and chemical analyses.

\section{Analytical method}

\section{Lead-210 $\left({ }^{210} \mathrm{~Pb}\right)$ dating}

${ }^{210} \mathrm{~Pb}$ activity (alpha spectrometry) was measured at the Korea Basic Science Institute (KBSI). Subsamples from 1 - to 40-cm depth were analyzed at intervals of $2 \mathrm{~cm}$ for ${ }^{210} \mathrm{~Pb}$ activity. ${ }^{210} \mathrm{~Pb}$ activities for non-analyzed intervals were interpolated. The supported ${ }^{210} \mathrm{~Pb}$ activity was estimated from the total ${ }^{210} \mathrm{~Pb}$ activity by assuming that the background activity of total ${ }^{210} \mathrm{~Pb}$ in the bottom portion of the core represented the supported ${ }^{210} \mathrm{~Pb}$ activity (Binford 1990; Kim et al. 2001). The ages of these sediments were calculated from the unsupported ${ }^{210} \mathrm{~Pb}$ activity using the Constant Rate of Supply (CRS) model (Appleby and Oldfield 1978).

\section{Pollen analysis}

Pollen analysis was conducted at $1 \mathrm{~cm}$ intervals throughout the $60-\mathrm{cm}$ sediment core using a modified standard method (Faegri and Iverson 1989) that included $\mathrm{KOH}$ treatment, $\mathrm{ZnCl}_{2}$ flotation, dehydration, and acetolysis. Two tablets of Lycopodium (batch 938934, Dept. of Quaternary Geology, Lund University) were added to each sample as an exotic tracer (Kim et al. 2001; Kim 2003). We counted pollen up to 300 grains or 100 Lycopodium spores per sample. Pollen taxa were identified at a magnification of $\times 400$ by referring to a pictorial book of Korean pollen (Chang and Rim 1979; Chang 1986). The identified pollen taxa were divided into three groups: arboreal, herb, and aquatic/wetland. The percentages of arboreal and herb pollen were calculated by dividing each group sum by the sum of arboreal and herb pollen. Percentages of aquatic taxa were calculated based on the terrestrial and aquatic taxa sum (Faegri and Iverson 1989). Pollen counts were converted to concentrations based on Lycopodium spores and sample amount (Kim et al. 2001; Kim 2003). Some rare herbaceous plant taxa observed were omitted from the pollen diagram.

\section{Physical and chemical stratigraphy}

Bulk density was calculated as dry weight per wet volume. Fresh wet sediment was weighed immediately and dried at $105^{\circ} \mathrm{C}$ for more than $24 \mathrm{~h}$ to measure dry mass. Organic matter content was determined with a loss on ignition by combustion in a muffle furnace at $550{ }^{\circ} \mathrm{C}$ for 4 h (Dean 1974). Total carbon and total nitrogen contents were determined using an elemental analyzer (Flash EA 1112 Series CHNS-O Analyzer, Thermo Finnigan) at The National Instrumentation Center for Environmental Management (NICEM) of Seoul National University. To determine concentrations of heavy metals (As, $\mathrm{Cd}, \mathrm{Cr}, \mathrm{Cu}, \mathrm{Ni}, \mathrm{Pb}, \mathrm{Zn}$ ) and total phosphorus (P), $0.50 \mathrm{~g}$ of sediment sample was digested with $10 \mathrm{ml}$ of nitric acid (trace metal grade, Fisher Scientific) in a closed microwave digestion system (MarsXpress, CEM, Program no. EPA 3051-24-Xpress) following the EPA 3051 method. Total P and heavy metal contents were measured with an inductively coupled plasma mass spectrometer (Varian 820-MS, Varian) at NICEM.

\section{Results}

\section{Depth-age model and accumulation rate}

The ${ }^{210} \mathrm{~Pb}$ profile showed relatively constant activity in the top $20 \mathrm{~cm}$ of the core. However, an abrupt change in activity was observed at 22-cm depth (Fig. 2a). Below 23 $\mathrm{cm}$, total ${ }^{210} \mathrm{~Pb}$ activity declined with small-amplitude fluctuations, reaching supported levels below $40 \mathrm{~cm}$. Supported ${ }^{210} \mathrm{~Pb}$ activity was determined as $39.3 \pm 2.5$ $\mathrm{mBq} \mathrm{g} \mathrm{g}^{-1}$, estimated as the mean activity over the deepest four samples (Fig. 2a). Therefore, the ${ }^{210} \mathrm{~Pb}$-based chronology is constrained for the upper $40 \mathrm{~cm}$ of the core. The sediment at $40-\mathrm{cm}$ depth was dated to AD 1863 (Fig. 2b).

Calculation of sedimentation and accumulation rate of the sediment core was based on changes in unsupported ${ }^{210} \mathrm{~Pb}$ activities with depth. The mass sediment accumulation rate was around $1.08 \mathrm{~kg} \mathrm{~m}^{-2}$ year $^{-1}$ from AD 1863 to 1930, showed two abrupt peaks over AD 1930-1960, and became a gradual increase to the top of the core (squares with a solid line in Fig. 3). The organic matter 

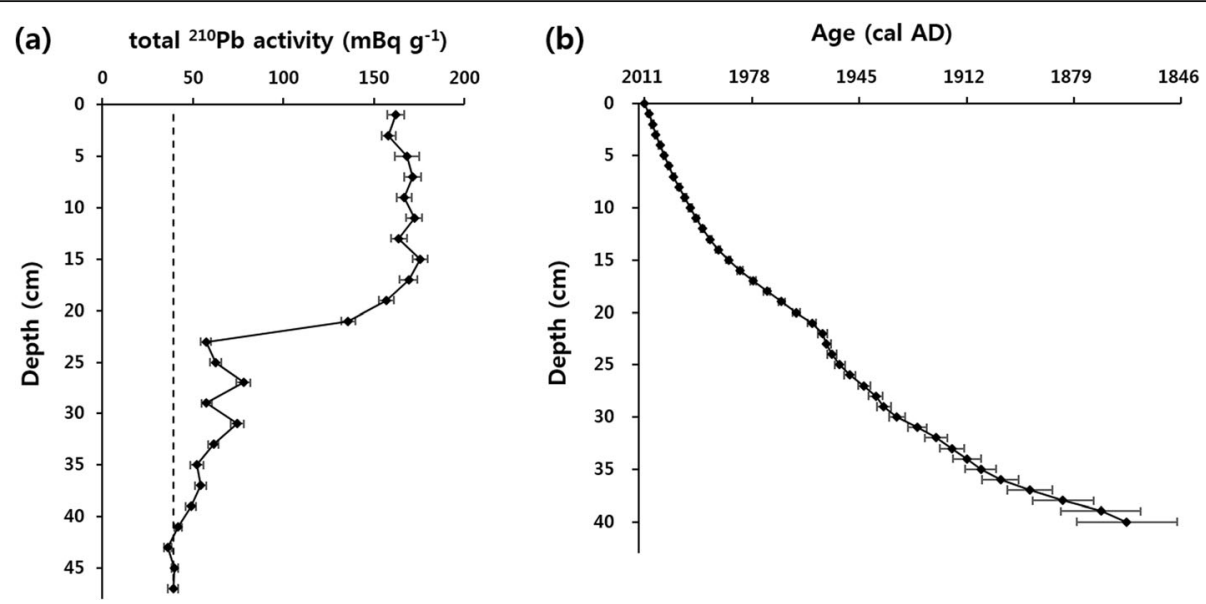

Fig. 2 Total ${ }^{210} \mathrm{~Pb}$ activity with depth $(\mathbf{a})$ and ${ }^{210} \mathrm{~Pb}$ dates with depth profiles (b) of the Yonghwasil-mot sediment core

accumulation rate (triangles with dashed line in Fig. 3) demonstrated similar trends with the mass sediment accumulation rate, ranging from 0.10 to $0.59 \mathrm{~kg} \mathrm{~m}^{-2}$ year $^{-1}$.

\section{Pollen stratigraphy}

The pollen composition analysis indicated that pine is the most abundant species since the AD 1930s, given that the pine pollen concentration explains $\sim 96 \%$ of the variance of the total pollen concentration $\left(r^{2}=0.957, p\right.$ $<0.001$ ) (Fig. 4). Gramineae pollen appeared steadily for the whole period. Between $60-$ and $40-\mathrm{cm}$ depth, the percentage of Alnus pollen decreased gradually while that of Pinus pollen increased. Cyperaceae and Artemisia pollen occurred in this period. The pollen concentration in this period was relatively low, with an average of 2.24 $\times 10^{5}$ grains $\mathrm{g}^{-1}$. In the AD 1980s, pollen concentrations abruptly exceeded $100 \times 10^{5}$ grains $\mathrm{g}^{-1}$ and pollen deposition remained relatively high until recent years.

\section{Biogeochemical properties}

The Yonghwasil-mot sediment core consisted mostly of brownish-gray silty clay. The bulk density decreased continuously from a maximum at $47-\mathrm{cm}$ depth to the surface. In contrast, the water content increased gradually in shallower layers, but decreased in the upper few centimeters. The decreasing water content in the upper layers was probably due to the temporary drainage of the Yonghwasil-mot during the sampling period. The organic matter $(\mathrm{OM})$, total carbon (TC), total nitrogen (TN), and total phosphorous (TP) contents maintained near-constant levels below 23-cm depth (before AD 1956), but showed an abrupt transition over the 21-23-

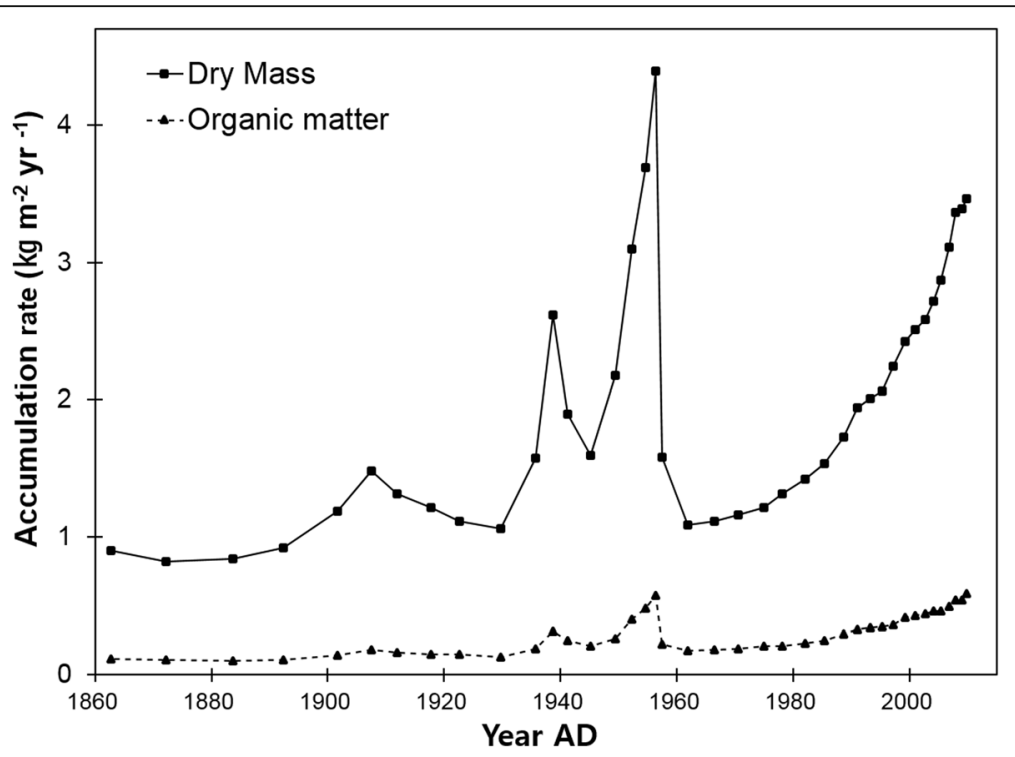

Fig. 3 Changes in sediment accumulation rate (SAR) over time inferred from the ${ }^{210} \mathrm{~Pb}$-based chronology 


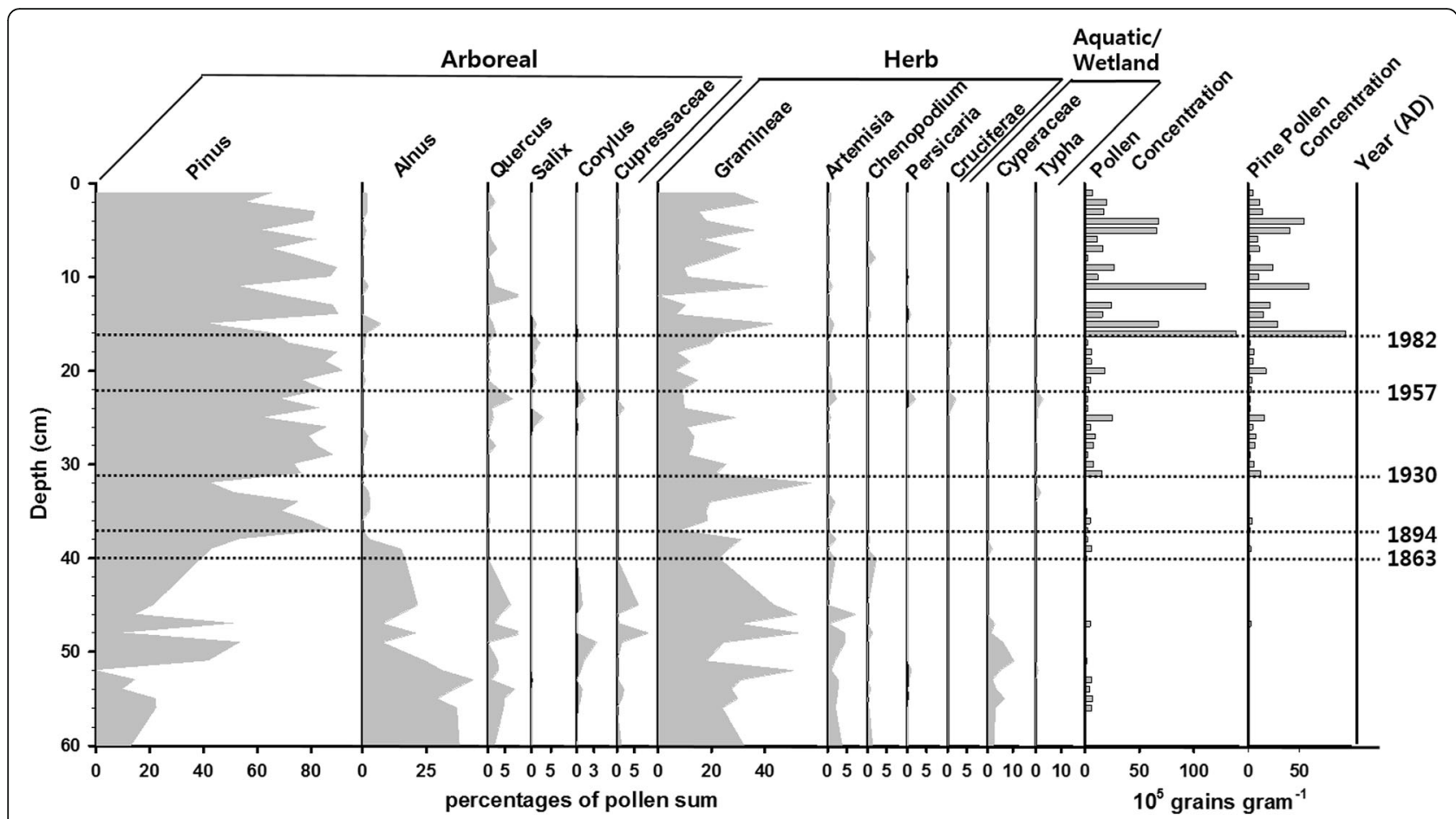

Fig. 4 Pollen percentage profiles of the Yonghwasil-mot sediment core. Horizontal lines indicate ${ }^{210} \mathrm{~Pb}$-derived sediment dates

cm interval (Fig. 5). The OM, TC, TN, and TP contents in the upper $20 \mathrm{~cm}$ section were significantly higher than those in the deeper layers. The carbon to nitrogen ratio $(\mathrm{C} / \mathrm{N}$ wt ratio) above the $44-\mathrm{cm}$ depth displayed a stable value from 9.0 to 11.3 . $\mathrm{C} / \mathrm{N}$ values generally decreased over time, with the highest value being 16.03. TP remained fairly constant between $40-$ and $23-\mathrm{cm}$ depth (average of $576.9 \mathrm{mg} \mathrm{kg}^{-1}$ ). However, this value increased by about three times above 22-cm depth.

\section{Heavy metal profiles}

Concentrations of most heavy metals changed in three stages (Fig. 6). Metal concentrations in sediments below 44-cm depth indicated natural background levels. Subsequently, metal concentrations other than those of $\mathrm{Ni}$ and $\mathrm{Cr}$ increased in two stages, one at 44-cm depth and the other at 22-cm depth. $\mathrm{Ni}$ and $\mathrm{Cr}$ had their highest concentrations at $40-\mathrm{cm}$ depth. They changed in similar patterns, unlike other heavy metal profiles. At $26-28 \mathrm{~cm}$

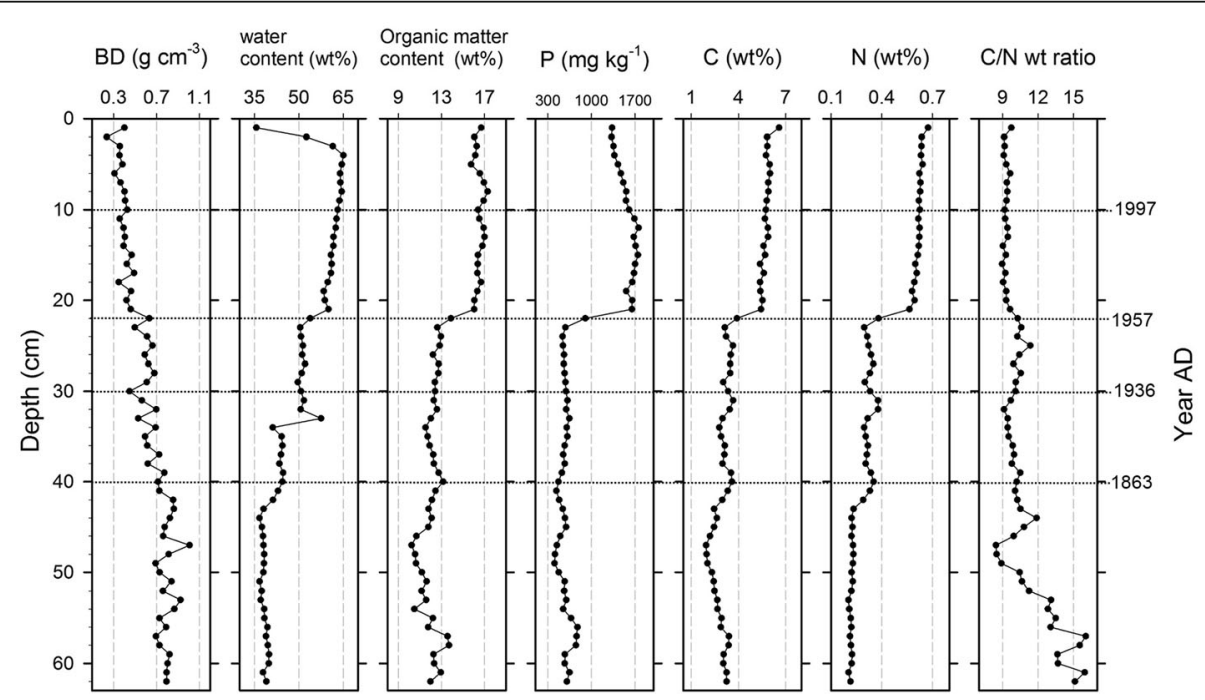

Fig. 5 Physical and chemical variables in the Yonghwasil-mot sediment core 
and $31-33 \mathrm{~cm}$ in depth, peaks were observed in the profiles of $\mathrm{As}, \mathrm{Pb}, \mathrm{Cd}$, and $\mathrm{Cu}$. Since the AD 2000s, concentrations of heavy metals, such as $\mathrm{As}, \mathrm{Pb}$, and $\mathrm{Cu}$, in the study area decreased gradually.

\section{Discussion}

\section{Sedimentology}

The sediment accumulation rate (SAR) exhibited a gradual increase since the late nineteenth century toward the present, interrupted by two spikes over the 1940-1960 periods (Fig. 3). The increases in SAR in the second half of the twentieth century have been observed from multiple lowland lake sediments and mainly attributed to recent urbanization, land-use change, and agricultural practices (e.g., Routh et al. 2004; Kim 2005; Rose et al. 2011; Borges and Nittrouer 2016). Enhanced runoff caused by increased precipitation is unlikely because the precipitation records from the six weather stations covering since the early twentieth century exhibit no significant precipitation increase during this interval around Korean Peninsula (located in Seoul, Mokpo, Daegu, Busan, and Gangreung) (Jung et al. 2011). In particular, the abrupt reduction of SAR in the 1960s in the Korean Peninsula was attributed to forest devastation by the Korean War (Kim 2005).

Our SAR data share common features with the results obtained from different study sites in the Korean Peninsula. Previous results from two reservoirs located in the south-eastern coast of the Korean Peninsula exhibited a rapid increase in SAR in recent decades (Kim 2005). In detail, a study site (Sangge reservoir) which is closer to the industrial complexes, showing a gradual increase since the 1940s and an abrupt increase from the 1980s because of the development of heavy industries (Kim 2005). In the meanwhile, the other site (Mujechi-neup), a montane Ramsar wetland with an altitude over $500 \mathrm{~m}$ a.s.l., has lower SAR by a factor of $\sim 10$ than Sangge reservoir and exhibits an abrupt decrease in the 1960s (Kim 2005) presumably due to the Korean War. The wellpreservation environment and higher elevation might make this site (Mujechi-neup) more sensitive to the impact of the Korean War, while less sensitive to heavy industries in the watershed area. Considering the geographical closeness, the different evolution of SAR in the two sites underlines the impact of heavy industries on SAR. Our results from Yonghwasil-mot show both aspects-abrupt decrease in the 1960s followed by a gradual increase, indicating that this site might have been affected by industrialization and the Korean War. The recent increase in mass sediment accumulation rate in Yonghwasil-mot might also be related to the construction of buildings and paved road in the surrounding area (Kim and Kim 2010). Our findings add to the evidence that the industrialization and urbanization during the twentieth century affected the western coast of the Korean Peninsula.

Further, the phosphorus accumulation rate in Yonghwasil-mot was much higher than those found in Anderson Marsh and in enriched areas of the Everglades (Kim 2003), implying that the nutrient input into Yonghwasil-mot has been relatively high (Table 1).

\section{Vegetation and water level change}

The history of the water level change at Yonghwasil-mot was qualitatively inferred from the pollen records. The pollen percentage profiles can be divided by three stages (Fig. 4). The interval below 44-cm depth is characterized as the maxima of the Alnus pollen occurred with Querqus species, indicating relatively wet and warm conditions (Yi et al. 2008). As the Cyperaceae and Poaceae

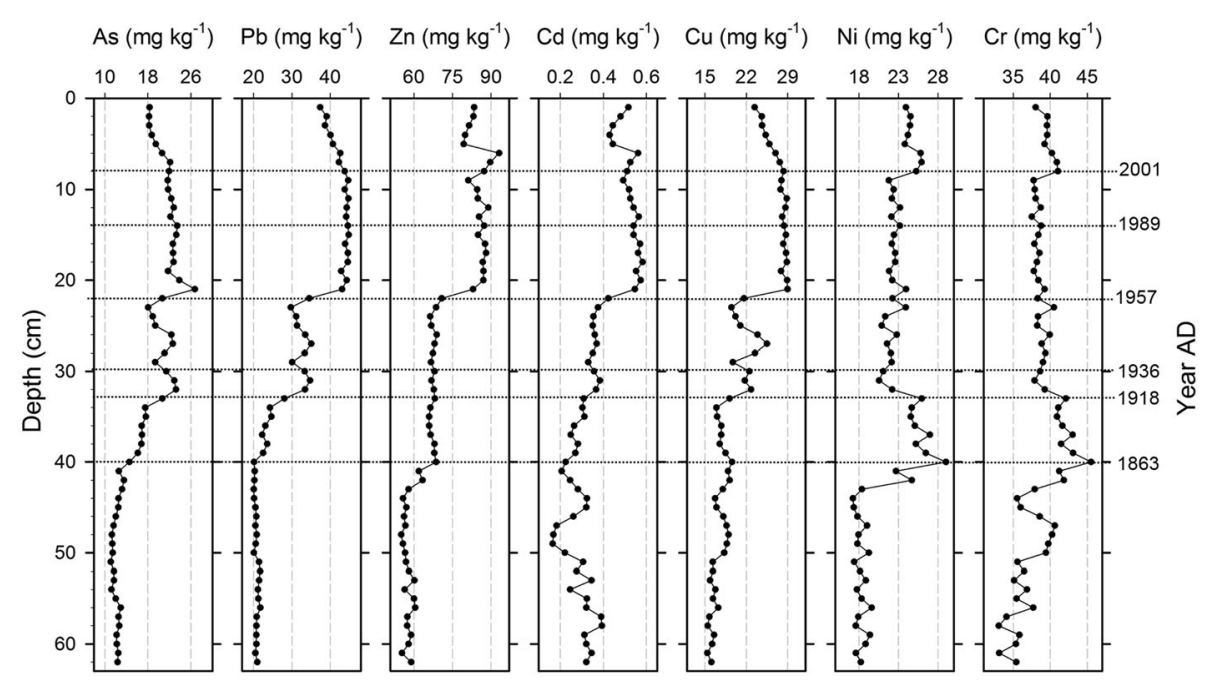

Fig. 6 Major heavy metal concentrations in the Yonghwasil-mot sediment core 
species favor the moist conditions (Hilbig 1995; Fowell et al. 2003), the higher abundances of Cyperaceae and Poaceae (Gramineae) in this stage further support the predominant wetland environment (Zhu et al. 2009; Miehe et al. 2014; Li et al. 2019), before construction of the Yonghwasil-mot as an agricultural reservoir. The elevated percentage of the Gramineae pollen is generally reflecting rice cultivation (e.g., Shen et al. 2005; Li et al. 2012; Park and Shin 2012); however, the low pollen density during this stage could be the result of low pollen inflow due to long dispersal distance or low pollen production (e.g., Van Campo et al. 1996; Brewer et al. 2017). Additionally, recurrent wetting and drying of sediment due to low water levels, indicating a harsh depositional environment, can cause the destruction of pollen grains and lower the pollen abundance (Bradbury and Van Metre 1997). Organic matter content fluctuated below $44 \mathrm{~cm}$ in depth compared to that in the upper part of the core (Fig. 5). The average $\mathrm{C} / \mathrm{N}$ wt ratio below 44-cm depth was 12.28 . The highest value was 16.03 , although $\mathrm{C} / \mathrm{N}$ wt ratio decreased over time. It has been reported that $\mathrm{C} / \mathrm{N}$ wt ratios of 13-14 for sediments suggest a sub-equal mixture of algal and vascular plant contribution (Meyers and Teranes 2001). It may also represent the slow growth of plankton (Rubio et al. 2003). Because of the low water level, land-derived material might have been introduced into wetlands easily during this period. This could be the reason why organic matter content and $\mathrm{C} / \mathrm{N}$ wt ratio are high and fluctuating.

The second stage of water level was observed at depths of 44 to $22 \mathrm{~cm}$. A gradual increase in pollen concentration above 31-cm depth (AD 1930) may reflect changes in vegetation density, increased pollen productivity, and raised water level, implying a more stable depositional condition than before. Furthermore, fruits of Trapa japonica Flerow, a floating-leaved aquatic plant that grows in many lentic habitats and is sensitive to water level change (Kim et al. 2011; Nishihiro et al. 2014), were detected occasionally from 40-cm depth (around AD 1860) to the present. This implies that the water level at the study site had been maintained above $50 \mathrm{~cm}$ during most of the period since that time. An abrupt transition is observed over 44 to $38 \mathrm{~cm}$ depths where the percentages of Alnus and Gramineae decrease while Pinus increases. Both the decrease in Alnus and increase in Pinus indicate the anthropogenic deforestation-reforestation procedures (e.g. Yi et al. 2008), reflecting the historical fact that most wetlands in the study area were reclaimed for agricultural land (Park and Shin 2012). During this period, there was a large demand for irrigation to increase rice production around the Seocheon area. Partly because of this circumstance, Yonghwasilmot's water storage should have increased. The increased $\mathrm{OM}$ and stable $\mathrm{C} / \mathrm{N}$ ratio support the increase of water level and stabilized depositional condition. The $\mathrm{C} / \mathrm{N}$ wt ratio of around 6-12 in the sediments indicates planktonic algae and other autochthonous organic matter (Olsson et al. 1997; Meyers et al. 1998) and decreased land-derived nutrients.

The uppermost $22 \mathrm{~cm}$ of the core exhibits the highest water level. The increase in pollen concentration of pine species by a factor of 7 since AD 1982 indicates the elevation of water level (Fig. 4). This change could be related to the reforestation movement in Korea in the 1970s, during which small trees were cut, and pines were planted in most mountains (Kim 2002), but also to the Korean War because of frequent forest fire and extensive harvesting of timber trees (Kim 2005). Meanwhile, OM, $\mathrm{TN}$, and TP increased as a result of the elevated nutrient input to Yonghwasil-mot during this period. This transition coincided with the socioeconomic movement in Korea that commenced from the 1960s, during which fertilizers, livestock, sewage, pesticides, and modern farming equipment were broadly disseminated (Park 2003). The overall ranges of TP are similar to those observed in other agricultural reservoirs in western Korea, where sediments were contaminated by sewage and livestock (e.g., Lee and Oh 2018).

\section{Heavy metal pollution}

Prominent anthropogenic activities such as traffic, construction of roads and buildings, and operation of industrial facilities have augmented the transport of soluble

Table 1 Comparison of sediment accumulation rates (SAR) and element accumulation rates

\begin{tabular}{|c|c|c|c|c|c|}
\hline Region & SAR $\left(m m\right.$ year $\left.^{-1}\right)$ & $\begin{array}{l}\text { Dry mass } \\
\left(\text { kg m }^{-2} \text { year }^{-1}\right)\end{array}$ & $\begin{array}{l}\text { Organic carbon } \\
\left(\mathrm{kg} \mathrm{m}^{-2} \text { year }^{-1}\right)\end{array}$ & $P\left(g^{-2}\right.$ year $\left.^{-1}\right)$ & Source \\
\hline Yonghwasil-mot & $0.91-8.88$ & $0.79-4.27$ & $0.10-0.59$ & $41.85-456.71$ & This study \\
\hline Sanggae reservoir & 2.91 & $2.1-6.0$ & $0.01-0.8$ & - & Kim (2005) \\
\hline Mujechi-neup & $0.10-0.12$ & $0.2-0.4$ & $0.09-0.3$ & - & Kim (2005) \\
\hline Upo wetland & $0.4-10$ & $0.7-2.3$ & - & - & Kim and Kim (2010) \\
\hline Anderson Marsh & $4.1-5.2$ & $1.07-1.38$ & $0.11-0.16$ & $1.17-1.32$ & Kim (2003) \\
\hline Everglades & $1.6-4.0$ & $0.14-0.36$ & $0.005-0.010$ & $0.06-0.14$ & $\begin{array}{l}\text { Craft and Richardson } \\
\text { (1993); Kim (2003) }\end{array}$ \\
\hline
\end{tabular}


and particulate forms of nutrients and heavy metals from watershed and atmosphere, which are recorded in sediment (Boynton et al. 1995; Carpenter et al. 1998; Kim 2003). Our results indicate the increase in $\mathrm{As}, \mathrm{Pb}$, and $\mathrm{Cu}$ concentrations over the AD 1920s (Fig. 6), coincident with abrupt industrialization commenced by the construction of railroads and ports in Janghang that were opened at the beginning of the 1930s (Park and Sung 2012). Furthermore, the Janghang smelter started operation in 1936 and mainly refined gold. In the course of smelting, pollutants such as sulfuric acid gas, Cd, As, and $\mathrm{Pb}$ were fumed through its $90 \mathrm{~m}$ smokestack on a stony mountain with an altitude of $120 \mathrm{~m}$ above sea level (Castro and Sánchez 2003; Hocking et al. 1978; Kim 2014). However, the industrial activities were temporarily shutdown from 1945 to 1953 due to abrupt changes in socio-political environments, such as the independence of Korea and the Korean War. During this interval, reductions of $\mathrm{As}, \mathrm{Pb}, \mathrm{Zn}$, and $\mathrm{Cu}$ concentrations were recorded. The smelter and other industries were reactivated from the late $1950 \mathrm{~s}$, and $\mathrm{As}, \mathrm{Pb}, \mathrm{Zn}, \mathrm{Cu}$, and $\mathrm{Cd}$ concentrations increased compared to the temporary shutdown period. The heavy metal concentrations started to decrease between the AD 1990s and the early 2000s following the closure of the main smelter in 1989. In the AD 1990s, most of the heavy metal concentrations, except for decreasing $\mathrm{Zn}$ and $\mathrm{Cd}$ concentrations, $\mathrm{Zn}$ and $\mathrm{Cd}$ are abundantly supplied by tire wear (Hopke et al. 1980; Taylor and Owens 2009). Their concentrations reflect the increased traffic in Seocheon. $\mathrm{Pb}$ was used as an anti-knock agent in gasoline in Korea until 1993. Therefore, $\mathrm{Pb}$ contents in sediments can reflect the usage of leaded gasoline (Renberg et al. 1994; Kim 2005). Because the Korean government banned the use of leaded gasoline in 1993, the recent decline in $\mathrm{Pb}$ contents (Murray and Gottgens 1997; Kim 2005) observed in the study area is reasonable. The Janghang smelter was located approximately $6 \mathrm{~km}$ southwestward of the core site, and many studies have reported high levels of anthropogenic metals from the Janghang smelter in the surface soil in the vicinity of the smelter (Kim and Baek 1994; Kim et al. 1996; Woo et al. 2010; Jeong et al. 2011). Considering the wind direction of the study area (Fig. 7) and that the Janghang smelter had a high smokestack, the heavy metal concentrations presented in this study imply that pollutant emissions from the smelter were higher than observed and that the contaminations in the lee side might be higher than those at the study site.

\section{Conclusion}

In this study, we reconstructed paleoenvironmental changes at Yonghwasil-mot, in the western coast of the Korean Peninsula, to assess the influences of rapid socio-economic development during the last few decades on different environmental aspects. Our major findings are summarized as follows:

The study site shows a higher nutrient influx than other water reservoirs in Korea, probably because of chemical fertilizer use in nearby agricultural land. Reconstructions of past changes in water level and pollen composition imply that, before the mid-nineteenth century, the Yonghwasil-mot was a shallow wetland under a relatively dry environment that is a harsh condition for pollen deposition. Since the mid-1950s, the water level increased and the study site became a pond in coincidence with the expansion of farmland. Later, the pine species dominated due to the government implemented afforestation since the 1970s. The influence of industrialization began to appear in the late 1890s in the study area. Constructions of the Janghang train line and station and the Janghang smelter were visible in the sediment based on increased metal concentrations. $\mathrm{Pb}$ profile also indicated the consumption of leaded gasoline. $\mathrm{Zn}$ and $\mathrm{Cd}$ reflected an increase of traffic in Seocheon.

1) The SAR evolutions since the 1930s exhibit coincident changes with socio-economic development and historical events around the study site.

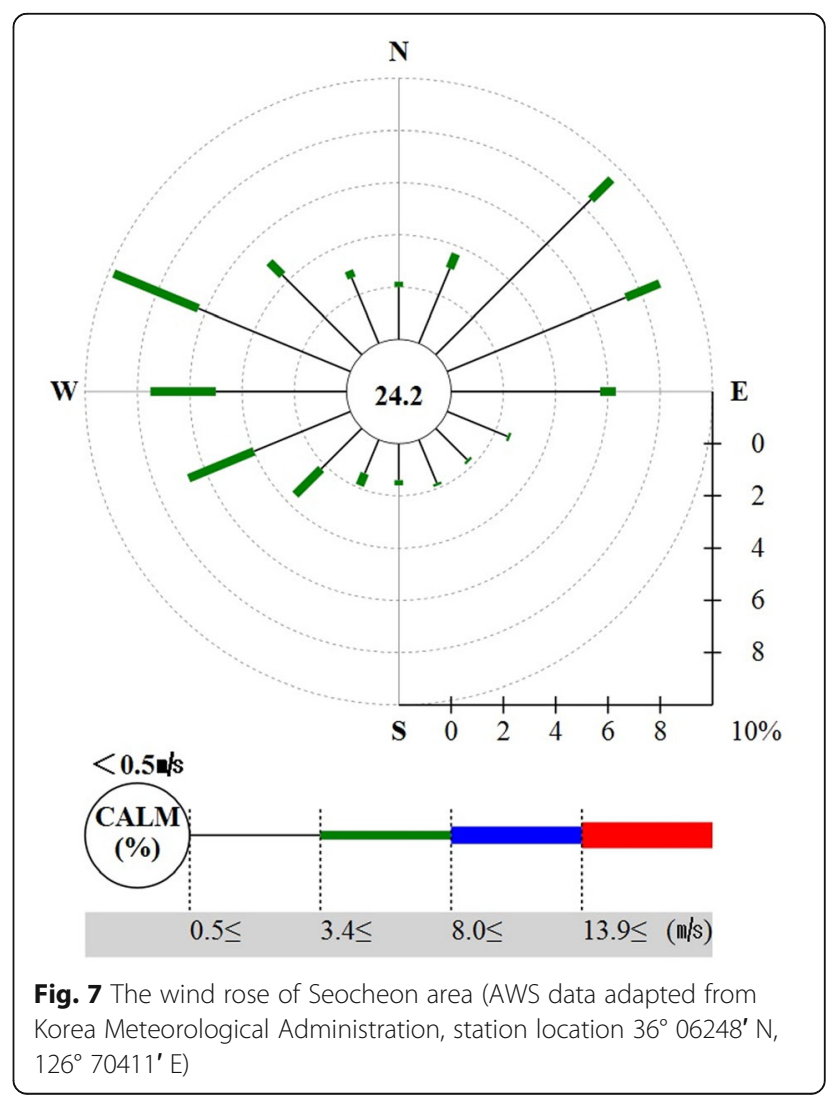


2) Vegetation and water level reconstructions imply that the Yonghwasil-mot was a shallow wetland under a relatively dry climate before the midnineteenth century. Since the mid-1950s, the water level increased and the study site became a pond coincident with the expansion of farmland. Later, pine species became dominant due to the governmentimplemented afforestation since the 1970s.

3) The influences of smelting activity are clearly recorded in heavy metal ( $\mathrm{As}, \mathrm{Cu}, \mathrm{Cd}, \mathrm{Pb}$, and $\mathrm{Zn}$ ) concentrations of the sediment core. The metal pollutions occurred since the 1930s when the Janghang smelter was constructed and reduced during the temporary shutdown period. In addition, $\mathrm{Cd}, \mathrm{Pb}$, and $\mathrm{Zn}$ concentrations also reflect recent urbanization in Seocheon area.

\section{Acknowledgements}

We appreciate Professor Chang-Seok Lee (Seoul Women's University) for providing information about the sampling site. We also thank Ji-Hyun Yoon (National Institution of Ecology) for helping background investigation of Yonghwasil-mot.

\section{Authors' contributions}

RYC, HTK, and JGK conceived and designed the research. JGK and HTK did the drilling of the sediment core, and RYC performed sample analysis. RYC, JGK, and JWY performed data interpretations and discussions. RYC and JWY led the manuscript writing, and the authors read and approved the final manuscript.

\section{Funding}

TBD

\section{Availability of data and materials}

All data used in this study are available upon request to the corresponding author.

\section{Ethics approval and consent to participate}

Not applicable.

\section{Consent for publication}

Not applicable.

\section{Competing interests}

The authors declare that they have no competing interests.

\begin{abstract}
Author details
'Department of Biology Education, Seoul National University, Seoul 08826, South Korea. ${ }^{2}$ Department of Biology Education, Seowon University, Cheongju-si, Chungbuk 28674, South Korea. ${ }^{3}$ Laboratoire des Sciences du Climat et de l'Environnement, Institut Pierre Simon Laplace, Université Paris-Saclay, 91191 Gif-sur-Yvette, France. ${ }^{4}$ Center for Education Research, Seoul National University, Seoul 08826, South Korea.
\end{abstract}

Received: 2 August 2020 Accepted: 31 August 2020

Published online: 12 October 2020

\section{References}

Appleby PG, Oldfield F. The calculation of lead-210 dates assuming a constant rate of supply of unsupported ${ }^{210} \mathrm{~Pb}$ to the sediment. Catena. 1978:5(1):1-8.

Binford MW. Calculation and uncertainty analysis of ${ }^{210} \mathrm{~Pb}$ dates for PIRLA project lake sediment cores. J Paleolimnol. 1990;3(3):253-67.

Borges HV, Nittrouer CA. Sediment accumulation in Sepetiba bay (Brasil) during the Holocene: a reflex of the human influence. J Sediment Environ. 2016;1(1): 90-106.
Boynton WR, Garber JH, Summers R, Kemp WM. Inputs, transformations, and transport of nitrogen and phosphorus in Chesapeake Bay and selected Tributaries. Estuaries. 1995;18:285-314.

Bradbury JP, van Metre PC. A land-use and water quality history of White Rock Lake reservoir, Dallas, Texas, based on paleolimnological analyses. J Paleolimnol. 1997:17:227-37.

Brewer S, Giesecke T, Davis BAS, Finsinger W, Wolters S, Binney H, de Beaulieu JL, Fyfe R, Gil-Romera G, Kühl N, Kuneš P, Leydet M, Bradshaw RH. Late-glacial and Holocene European pollen data. J Maps. 2017;13(2):921-8.

Carpenter SR, Caraco NF, Correll DL, Howarth RW, Sharpley AN, Smith VH. Nonpoint pollution of surface waters with phosphorus and nitrogen. Ecol Appl. 1998;8(3):559-68.

Castro SH, Sánchez M. Environmental viewpoint on small-scale copper, gold and silver mining in Chile. J Clean Prod. 2003;11:207-13.

Chang NK. Pollens, Illustrated Flora \& Fauna of Korea, vol. 29. Seoul: Ministry of Education; 1986. (in Korean).

Chang NK, Rim YD. morphological studies on the pollen of flowering plants in Korea. Seoul: Seoul National University Press; 1979. (in Korean).

Cho J, Hyun S, Han JH, Kim S, Shin DH. Historical trend in heavy metal pollution in core sediments from the Masan Bay, Korea. Mar Pollut Bull. 2015;95(1):427432.

Craft CB, Richardson CJ. Peat accretion and N, P, and organic accumulation in nutrient-enriched and unenriched Everglades peatlands. Ecol Appl. 1993;3: 446-58.

Dean WE. Determination of carbonates and organic matter in calcareous sediment and sedimentary rocks by loss on ignition: comparison with other methods. J Sediment Petrol. 1974;44:242-8.

Facevicova K, Kynclova P, Upadhyaya S. How industrial development matters to the well-being of the population: some statistical evidence. Vienna: United Nations Industrial Development. Organization. 2020.

Faegri K, Iverson J. Textbook of pollen analysis. 4th ed. Chichester: Wiley; 1989.

Fowell SJ, Hansen BCS, Peck JA, Khosbayar P, Ganbold E. Mid to late Holocene climate evolution of the Lake Telmen Basin, North Central Mongolia, based on palynological data. Quat Res. 2003;59(03):353-63.

Hilbig W. The Vegetation of Mongolia. Amsterdam: SPB Academic; 1995.

Hocking D, Kuchar P, Plambeck JA, Smith RA. The impact of gold smelter emission on vegetation and soils of a sub-arctic forest-tundra transition ecosystem. J Air Pollut Control Assoc. 1978;28:133-7.

Hopke PK, Lamb RE, Natusch FS. Multielemental characterization of urban roadway dust. Environ Sci Technol. 1980;14:164-72.

Jeong S, An J, Kim YJ, Kim G, Choi S, Nam K. Study on heavy metal contamination characteristics and plant bioavailability for soil in the Janghang smelter area. J Soil Groundwater Environ. 2011;16(1):42-50 (in Korean with English abstract).

Jung IW, Bae DH, Kim G. Recent trends of mean and extreme precipitation in Korea. Int J Climatol. 2011;31:359-70.

Kim DG. Secondary damage from an environmental pollution in incident and the restoration process: focusing on a village near Janghang smelter. J Inst Soc Sci. 2014;25(3):267-95 (in Korean with English abstract).

Kim GY. Inhabitation of 13 Mandarins in National Institute of Ecology in Seocheon: Yunhap News Agency; 2012. http://news.naver.com/main/read. nhn? Mode $=$ LSD\&mid=sec\&sid $1=102 \&$ oid $=001$ \&aid $=0005810404$. Accessed 3 Aug 2020 (in Korean).

Kim H, Kim JG. A 2000-year environmental history of the Upo Wetland on the Korean Peninsula. J Paleolimnol. 2010;44(1):189-202.

Kim JG. A study on soil particle size in mountains of Seoul vicinity for forest restoration. J Korean Soc Environ Restoration Technol. 2002:5:1-8.

Kim JG. Response of sediment chemistry and accumulation rates to recent environmental changes in the Clear Lake Watershed, California, USA. Wetlands. 2003;23:95-103.

Kim JG. Assessment of recent industrialization in wetlands near Ulsan, Korea. J Paleolimnol. 2005;33:433-44.

Kim JG, Rejmánková E. The paleoecological record of human disturbance in wetlands of the Lake Tahoe Basin. J Paleolimnol. 2001;25:437-54.

Kim JG, Rejmánková E, Spanglet HJ. Implications of a sediment-chemistry study on subalpine marsh conservation in the Lake Tahoe Basin, USA. Wetlands. 2001;21(3):379-94.

Kim S, An J, Kim I, Cho U, Lee H, Hwang D. A study on the flora and distribution of vegetation in Reservoir Jangchuck. J Wet Res. 2011;13(3):657-64 (in Koran with English abstract). 
Kim S, Baek S. Variation of cadmium and zinc content in paddy soil and rice from the Janghang smelter area. Korean J Environ Agric. 1994;13(2):131-41 (in Korean with English abstract).

Kim S, Baek S, Moon K. Fraction of heavy metals and correlation with their contents in rice plant grown in paddy near smelter area. Korean J Environ Agric. 1996:15(1):1-10 (in Korean with English abstract).

Lee JK, Oh JM. A study on the characteristics of organic matter and nutrients released from sediments into agricultural reservoirs. Water. 2018;10(8):980

Li C, Zheng Y, Yu S, Li Y, Shen H. Understanding the ecological background of rice agriculture on the Ningshao Plain during the Neolithic Age: pollen evidence from a buried paddy field at the Tianluoshan cultural site. Quat Sci Rev. 2012;35:131-8.

Li M, Song H, Woods AD, Dai X, Wignall PB. Facies and evolution of the carbonate factory during the Permian-Triassic crisis in South Tibet, China. Sedimentology. 2019;66(7):3008-28.

Liu Y, Yu N, Li Z, Wei Y, Ma L, Zhao J. Sedimentary record of PAHs in the Liangtan River and its relation to socioeconomic development of Chogqing, Southwest China. Chemosphere. 2012;89:893-9.

Mackereth FJH. Some chemical observations on post-glacial lake sediments. Philos Trans R Soc Lond Ser B Biol Sci. 1966;250(765):165-213.

Meyers PA, Tenser GE, Lebo ME, Reuter JE. Sedimentary record of sources and accumulation of organic matter in Pyramid Lake, Nevada, over the past 1,000 years. Limnol Oceanogr. 1998:43(1):160-9.

Meyers PA, Teranes JL. Sediment organic matter. In: Last WM, Smol JP, editors. Tracking Environmental Change Using Lake Sediments. Physical and Geochemical Methods, vol. 2. Dordrecht: Kluwer Academic Publishers; 2001. p. 239-69.

Miehe S, Miehe G, van Leeuwen JFN, Wrozyna C, van der Knaap WO, Duo L. Persistence of Artemisia steppe in the Tangra Yumco Basin, wet-central Tibet, China: despite or in consequence of Holocene lake-level changes? J Paleolimnol. 2014;51(2):267-85.

Murray TE, Gottgens JF. Historical changes in phosphorus accumulation in a small lake. Hydrobiologia. 1997;345(1):39-44.

Nishihiro J, Kato Y, Yoshida T, Washitani I. Heterogeneous distribution of a floating-leaved plant, Trapa japonica, in Lake Mikata, Japan, is determined by limitations on seed dispersal and harmful salinity levels. Ecol Res. 2014;29: 981-9.

Olsson S, Regnéll J, Persson A, Sandgren P. Sediment-chemistry response to landuse change and pollutant loading in a hypertrophic lake. southern Sweden. J Paleolimnol. 1997;17(3):275-294.

Park JG. Technology, growth and agricultural development in Korea: past, present and future. Korea Agric Hist Assoc. 2003;2(2):105-27 (in Korean with English abstract).

Park JJ, Shin YH. Late-Holocene rice agriculture and palaeoenvironmental change in the Yeongdong region, Gangwon. South Korea. J Korean Geogr Soc. 2012; 47(5):641-53 (in Korean with English abstract).

Park JM, Sung JS. A study on the industrial heritage in Jang hang. Geogr J Korea. 2012;46(2):107-20 (in Korean with English abstract).

Renberg I, Persson MW, Emteryd O. Pre-industrial atmospheric lead contamination detected in Swedish lake sediments. Nature. 1994;368:323-6.

Rose NL, Morley D, Appleby PG, Battarbee RW, Alliksaar T, Guilizzoni P, et al. Sediment accumulation rates in European lakes since AD 1850: trends, reference conditions and exceedance. J Paleolimnol. 2011;45(4):447-68.

Routh J, Meyers PA, Gustafsson O, Baskaran M, Hallberg R, Scholdstrom A. Sedimentary geochemical record of human-induced environmental changes in the Lake Brunnsviken watershed, Sweden. Limnol Oceanogr. 2004;49(5): 1560-9.

Rubio L, Linares-Rueda A, Duenas C, Fernández MC, Clavero V, Niell FX, et al. Sediment accumulation rate and radiological characterization of the sediment of Palmones River estuary (southern of Spain). J Environ Radioact. 2003;65(3):267-80.

Shen J, Yang L, Yang X, Matsumoto R, Tong G, Zhu Y, et al. Lake sediment records on climate change and human activities since the Holocene in Erhai catchment, Yunnan Province, China. Sci China Ser D. 2005;48(3):353-63.

Song YS, Choi JY, Park KH. The Tectono-metamorphic evolution of metasedimentary rocks of the Nampo group outcropped in the area of the Daecheon Beach and Maryangri, Seocheon-gun, Chungcheongnam-do. J Petrol Soc Korea. 2008;17(1):1-15 (in Korean with English abstract).

Taylor KG, Owens PN. Sediments in urban river basins: a review of sedimentcontaminant dynamics in an environmental system conditioned by human activities. J Soils Sediments. 2009;9(4):281-303. van Campo E, Cour P, Sixuan H. Holocene environmental changes in Bangong Co basin (Western Tiben). Part 2: The pollen record. Palaeogeogr Palaeoclimatol Palaeoecol. 1996;120:49-63.

Woo S, Kim G, Kim Y, Nam K. Existing forms of heavy metals in the vicinity of a smelter. J Soil Groundw Environ. 2010;15(5):16-22 (in Korean with English abstract).

Yi C, Chen H, Yang J, Liu B, Fu P, Liu K, Li S. Review of Holocene glacial chronologies based on radiocarbon dating in Tibet and its surrounding mountains. J Quat Sci. 2008:23:533-43.

Yu S, Zhu YG, Li XD. Trace metal contamination in urban soils of China. Sci Total Environ. 2012:421:17-30.

Zhu L, Zhen X, Wang J, Lu H, Xie M, Kitagawa H, Possnert G. A 30,000-year record of environmental changes inferred from Lake Chen $\mathrm{Co}$, Southern Tibet. J Paleolimnol. 2009;42:343-58.

\section{Publisher's Note}

Springer Nature remains neutral with regard to jurisdictional claims in published maps and institutional affiliations.
Ready to submit your research? Choose BMC and benefit from:

- fast, convenient online submission

- thorough peer review by experienced researchers in your field

- rapid publication on acceptance

- support for research data, including large and complex data types

- gold Open Access which fosters wider collaboration and increased citations

- maximum visibility for your research: over $100 \mathrm{M}$ website views per year

At BMC, research is always in progress.

Learn more biomedcentral.com/submissions 